\title{
THE ROLE OF TWITTER IN THE FIRST WEEK OF FERGUSON UNRESTS IN AUGUST 2014.
}

\author{
Marcin Balon
}

\begin{abstract}
The purpose of this article is find out about the role that was played by Twitter during the first week of Ferguson Unrests that started on the 9th of August 2014.

As a source base for this work the author analyzes the newspapers, magazine journalism and articles upon the death of Michael Brown to show how local journalists and activists used Twitter to communicate and comment on his death. Through the examination of hashtag usage, the author demonstrates how Twitter has become a powerful tool to start nationwide discussion, as well as how hashtag activism can trigger creation of a new social movement.
\end{abstract}

Key words: Twitter, hashtag, civil journalism, social movement

\section{Introduction}

The objective of the article is to demonstrate, through analysis of the role that was played by Twitter in the first week of Ferguson Unrests, how powerful tool Twitter has become. In this article the author wants to verify the statement that activists commonly used Twitter as an instrument to communicate and organize the protests. Through the examination and analysis of various articles the author shows how Twitter has become a mighty weapon of civil journalism, as well as that "hashtag activism" can trigger the creation of a new social movement. As a source base for this work the author analyzes the newspapers, magazine journalism and articles from the moment of the death of Michael Brown. A number of qualitative research methods were applied in this article, such as description, observation, content analysis, secondary analysis, narrative analysis, and generalization.

The internet has changed the way people stay in contact despite immense physical distances. In a short period of time social media became the most dynamical form of communication, not only between friends, but also reaching wider audiences through its cross and cascading dissemination of the content. Lifting restrictions by simplifying an access to the internet connection as well as wide availability of the communication tools allow ordinary people to express their opinion on a range of social, political, and cultural issues [Szewczyk, 2017, p. 338-339]. Twitter is an online news and social networking microblogging service that allows users to send and receive text-based messages or posts of up to 280 characters (until 7.11.2017 limit was 140 characters) called "tweets". 
Ever since it was launched in 2006, Twitter has grown to become a major, powerful force in social media, platform for businesses, organizations, and individuals alike. Today, millions of people around the world use Twitter to break and comment on news, circulate official statements, organize campaigns and protests, or simply as the Twitter homepage suggests, the social platform can be used to, "See what's happening in the world right now." Most of the accounts on Twitter have public status, which means that every user can reach to the published content [Leonowicz-Bukała I., Martens A., Ochnio J., 2015, p.12]. In 2014 about $23 \%$ of all internet users used Twitter on a regular basis (growth from $18 \%$ in 2013 and from $16 \%$ in 2012). Everyday $36 \%$ of Twitter users visit the site once a day and $22 \%$ browse Twitter a few times a day. [Duggan, M., Ellison, N. B., Lampe, C., Am Lenhart, A., \& Madden, M. 2015]. Twitter's user base has grown rapidly, reaching about 330 million active accounts in 2017 [Statista, 2017].

The simplicity of getting the news messages on Twitter has made it a significant source of information. The Pew Research Center studies in 2015 and 2017 found that Twitters' role as a source of news for its American users is evolving. Clear majority (74\%) say that the platform serves as a source of news. That share has increased substantially from 2013, when about half of users (52\%) said the same [Shearer, Gottfried, 2017]. People are more willing to use Twitter to find information on: national government and politics, international affairs, business, sports, people and events in your community, local weather and traffic, entertainment, crime, local government, science and technology, and health and medicine [Barthel M., Shearer E., Gottfried J., Mitchel A., 2015]. Twitter is often used as an event channel where groups of people organize Tweetups and meetings. Twitter is a very useful tool in business, moreover, a good marketing team can easily grow brand awareness, connect with potential customers, influencers or brand advocates. Using Twitter in customer service can help to easily and quickly respond to people for building good reputation and strengthening relations with clients.

\section{Use of Twitter by local journalists and activists}

Thousands of protesters went out on the streets of Ferguson, to demonstrate their frustration after the police shooting resulting in the death of African- American teenager Michael Brown on the 9th of August, 2014. Within minutes of his death members of local community and activists started to use social media to document the development of the protests resulting in a powerful police reaction and to draw attention to police violence. People could not believe what they were seeing on Twitter when scrolling through posts hashtaged \#Ferguson, \#BlackLivesMatter and \#MikeBrown.

"Ferguson police just executed an unarmed $17 \mathrm{yr}$ old boy that was walking to the store. Shot him 10 times smh," tweeted La'Toya Cash (@AyoMissDarkSkin) [Lewontin M., 2016]. "smh - shaking my head" is generally used to indicate disgust or incredulousness. Another post that appeared on the Twitter said " $F \star \star k f \star \star k ~ f \star \star k$ ", followed by a picture overlooking the road, where Michael Brown's dead body laid uncovered on the street [Carpentier, 2015]. In a few hours, Michael Brown's death has become symbolic. The hashtag \#Ferguson also has become a landmark for the social justice movement that spawned from Michael Brown's death. During the first week of protests, over 3.6 million posts referring to the shooting appeared on Twitter [Bonilla Y., Rosa J., 2015]. Between August 9th and August 25th, the hashtag \#Ferguson was used on Twitter 11.6 million with retweets and 1.9 million without retweets, according to Sysomos [Grinberg E., 2014]. Map showing how news of \#Ferguson spread across Twitter: srogers.carto. com/viz/4a5eb582-23ed-11e4-bd6b-0e230854a1cb/embed_map

Wide use of Twitter has accelerated national response during the first week from the moment of Michael Brown's death. Except for the mentioned La'Toya Cash, on 9th of August, the remaining local Twitter broadcasters were: Antonio French (@AntonioFrench), a St. Louis-based Democratic alderman, Goldie Taylor (@goldietaylor), a journalist and author, Kareem Jackson "Tef Poe" (@TefPoe), a St. Louis/Ferguson-based rapper, 
and local politician Chris Carter (@ChrisCarter3). Both French and Tef Poe were later arrested during the Michael Brown's killing protests. Out of the early initiators, only Antonio French managed to hold his high-profile status among the Twitter broadcasters during the first week of unrests. He was called by Mandaro and Snider to be "one reason Twitter become the place to see what was going on in Ferguson after the August 9 shooting death of Brown" [2014]. The number of French's followers on Twitter has sky-rocketed from 4179 on August 8th to 70101 week later and to finally reach 121291 people on the 24th of August. [Mandaro L., Snider J., 2014] French was sending up to 314 tweets a day, he seemed to be everywhere, trying to broadcast the events. Later, he was praised as he tried to represent peaceful and responsible approach to the very delicate problem of unrests by trying to calm down battle moods by negotiations with rioters. Other early participants, for example the person hiding under the nickname N $\triangle T E$ (@natedrug), actively taking part in protests, was the most widely re-tweeted user in the network for five days [Jackson S., Welles B., 2015]. Johnnetta Elzie (@Nettaaaaaaaa), who grew up in the St. Louis area, had just finished a job as a phone interviewer for the United States Department of Agriculture and was considering going back to school. She was an active demonstrator and her livestreamed video of the demonstrations brought her huge number of social media followers. Since then Johnnetta Elzie has become a prominent digital activist in the \#BlackLivesMatter movement, partly as a result of her role in the Ferguson protests [Lewontin M., 2016]. N $\Delta T E$ and Johnnetta Elzie's popularity in the network during Ferguson protests often outranked more traditional sources including CNN (@CNN) and a range of individual journalists [Jackson S., Welles B., 2015]. It is worth mentioning, that all these users are young African- Americans, without Twitter high-profile status or connections with media. On August the 10th the demonstrators gathered at a temporary memorial near the place where Brown was killed. That night brutality has begun with plundering at local shops and a firm response from police in military-styled gear. Unrest continued into the next day, forcing police to use tear gas as well as rubber bullets against protesters, some of whom are suspected to be firing guns at officers [Sanchez R., Lawler D., 2015]. From the 10th of August, members of Anonymous or BlackLivesMatter movements, bloggers and tweeters living outside of the Ferguson area also started appearing in the vicinity of unrests. One of them was DeRay Mckesson (@deray). He felt obliged to take part in the protests and drove for nine hours from Minneapolis to Missouri. The evening after his arrival he joined the crowd and was chased and tear gassed by police along with other demonstrators on the streets of Ferguson.

Mckesson was one of those who stimulated hashtag \#Ferguson to grow, as he actively took part in the protests. He tweeted images, news about protests and demonstrations. He also shared information about local accommodation and places to eat with visitors. "There was a lot of righteous rage, but also a deep sense of community and joy that outlined that anger," he said. "It turned me into being a committed protester" [Grinberg E., 2014]. For him it was also time to build relationships that would allow to start with Johnetta Elzie a peaceful movement "WeTheProtesters.org" [McDonald B., Archdeacon C., Chavar A.J., 2015] and online newsletter "This is the Movement". They were both ranked at 11th place of Fortune's list of "World's Greatest Leaders" as a "prominent voices for nonviolent protest" [Fortune.com, 2015]

Shaun King (@ShaunKing), an American writer, pastor and civil rights activist as well as a person hidden under the nickname Resist (@UntoldCarlisle), who describes himself as a "citizen journalist bringing you the raw, uncut truth" are also worth mentioning. These two users distributed biased information full of shocking images and violent actions of police on protesters.

"Anonymous" became active and started influencing the network on the 11th of August, using two or three different associated accounts at a time. These accounts included@YourAnonNews, @OpFerguson, @TheAnonMessage, and @YourAnonGlobal. Over the week Anonymous was the only activist organization that had gained real influence 
in the network. Due to their secret nature, the organization was able to offer a kind of non-objective viewpoint to the networked conversation about Ferguson that would have been far too risky for any individual citizen or activist to introduce. These messages were full of indignation at the suppression of the demonstrations as well as the brutality of the police and supplied the image of how the civil disobedience looks like by showing pictures filled with anger and exasperation [Jackson S., Welles B., 2015].

\section{Use of Twitter by traditional elite broadcasters.}

Traditional media played quite a poor role among Twitter broadcasters of the Ferguson unrests. From 11th of August and for the rest of the week, only two local news outlets and a few individual mainstream journalists' accounts did come into being on Twitter. Local news outlets, like KSDK News (@ksdknews), KMOV (@KMOV), and FOX 2 (@Fox2now) which represent NBC, CBS, and Fox affiliates, gave regular updates of various developments in Ferguson. Reports included photos and videos more similar to a war zone than an American city. Their mostly retweeted information was the confirmed hacking of the web services of the City of Ferguson by Anonymous, scope of the police reaction to protesters, police action demanding that media leave the scene (police officials in Ferguson intimated that they had no interest in broadcasting news from the demonstrations when officers tear-gassed Al Jazeera crew working on a stand-up far from the action) and probability of revealing the name of Michael Brown's shooter by the Police Department. This type of information was desired by network, while neither tweets about "looting" nor "positive updates about Ferguson events" did catch much attention [Jackson S., Welles B., 2015]. The power of the social media was appreciated by the local internet St. Louis Business Journal which on the 12th of August published an article "How to follow what's unfolding in Ferguson on Twitter". In the article, Kelly Moffitt [2014] named several worth following reporters Twitter accounts (i.e. Antonio French, Wesley Lowery) as well as specified four groups of hashtags:

- Relating to Michael Brown - \#MikeBrown, \#MichaelBrown

- Connected to unrests, protests and rioting - \#Ferguson, \#FergusonRiot, \#STLriots

- Movement to recognize how black youth are portrayed in the media - \#IfTheyGunnedMeDown

- Requests for positivity in the neighborhood - \#PrayforSTL

Web page with the article was updated for two consecutive days.

\section{Twitter as a tool of civil journalism in Ferguson}

The main role Twitter played in Ferguson Unrests, was to show the events from the protesters point of view in contrary to the traditional broadcasters. This case confirms arguments of Murthy [2011] who calls Twitter a form of citizen journalism. It also shows that public debates are not reserved only for the experienced activists or journalists. Power of social media allowed individual members of marginalized parts of the society take an active part in it. Sawicka [2017, p.35] says in her works that marginalized groups can not only create their own discourse in an existing public zone, but also create an alternative to the version presented by mainstream media. Social movements have been using media and technology for a long time to spread the news to wider publics. For Polish "Solidarity" Radio Free Europe was a voice of non-propaganda news and information; a VHS tape of Rodney King being beaten by the police sparked national riots in the USA; e-mails allowed Zapatistas to disseminate their global communiques. Of course, these types of media allowed only for passive broadcast of the information and thus, making it incomparable with social media. The main difference between these older forms of technology and Twitter is its interactivity - ability to respond and react in real time to the content, that creates a unique feeling of participation and unity across space and time and that makes it a perfect tool for citizen journalism [Bonilla Y., Rosa J., 2015]. 


\section{Twitter as an instrument to communicate and to organize the protests}

Protests in Fergusson did not have any leader, the biggest work organizing it there was done by tweets of DeRay McKesson and Johnetta Elzie. They have together developed a model of the modern protester, a hybrid of an organizer and citizen journalist. Basing on their experience gained in Ferguson, they have later set up an advocacy organization WeTheProtesters.org, that provides organizing, research, and policy advocacy support to protest groups. [Kang J.C., 2015]

We also have to underline Twitter's important role in catalyzing protests by making it easier for people to get the information about:

- Planned and actual location and timing of protests,

- Food give-away actions, restaurants, places to stay,

- How safe participation is (violence, looting, level of the response from the police),

- What is the current scale of protests.

The way people organize events has evolved, before social media people who organized protests were communicating either verbally (face to face or by telephone) or in writing (letters, leaflets and posters). The mobilizing function of social media was already described in several articles and books. Social media can influence the forming protest movements in a few ways [Tucker J., Metzger M., Penfold-Brown D., Bonneau R., Jost J., Nagler J., 2015]:

- By building a protest movement

- By recruiting new members and encouraging participation

- By broadcasting information about the movement,

A BBC journalist Paul Mason classified social media by its functionality: "Facebook is used to form groups, covert and overt-in order to establish those strong but flexible connections. Twitter is used for real-time organization and news dissemination, bypassing the cumbersome 'newsgathering' operations of the mainstream media. YouTube and the Twitter-linked photographic sites-Yfrog, Flickr and Twitpic-are used to provide instant evidence of the claims being made. Link-shorteners like bit.ly are used to disseminate key articles via Twitter". [Mason, 2012]

During the Arab Spring Jared Cohen tweeted citation of one of the Egyptian activists: "facebook used to set the date, Twitter used to share logistics, youtube to show the world, all to connect people". In an addition to that Twitter is affecting people's feelings (group identity, injustice) and emotions (anger, infirmity) that could trigger the decision to actively participate in protests.

\section{Hashtag activity}

Ahashtag (\#) is a type of metadata tag usually used as a method of tagging a conversation within Twitter, it works as a filing system. Those keywords are integral to the way we communicate on Twitter. It allows user to organize and receive information about a particular topic. Along with serving as an indexing system, hashtags enhance the message by indicating the expected importance of a statement. [Mistewicz, s.51]

Main reasons why people use hashtags in social media are:

- Hashtags help you to reach your target audience. By using the correct hashtag, you can increase the chances that your message is found.

- Hashtags improve your click-through rates. Research made by LinchpinSEO, showed that tweets with hashtags get twice as much attention as those that do not [www.linchpinseo.com, 2013 - 2018].

- Hashtags are great for research. A lot of people browse the internet basing their research on specific hashtags to find relevant content. 
- Hashtags become links to search queries. Clicking on the hashtag takes you to a search query related to the hashtag. [Brooks R., 2015]

After Michael Brown's death, as details were coming out about the protests starting in Ferguson, users started using the hashtag \#Ferguson in their tweets. That hashtag was ranked No. 1 on the Washington Post list of "10 Twitter hashtags that have changed the way we talk about social issues". Since its first use \#Ferguson has been tweeted 27,2 million times. Another hashtag related to events in Ferguson - \#BlackLivesMatter got 3rd place on the abovementioned list with $12 \mathrm{mln}$ tweets. [Sichynsky T., 2016] \#BlackLivesMatter was aslo chosen by American Dialect Society as a word of the year [R.L.G., 2015]. Since it was created in July 2013 \#BlackLivesMatter hashtag was rarely used. Its significance and usage skyrocketed partly due to the slogan's frequent use in the context of the Ferguson protests [Freelon D., Mcllwain c., Clark M., 2016]. In 2014 wide use and popularity of the hashtag during the protests on the streets of Ferguson pushed a new generation of activists both on the ground and online to form a new movement. The Black Lives Matter, which is now an international activist movement calling for change with how police deal with minorities, and demands a look at systemic racism and equity [Luibrand S., 2015].

Other hashtags such as \#IfTheyGunnedMeDown and \#HandsUpDontShoot have triggered an online conversation about race and justice. [Daly N., 2014] \#IfTheyGunnedMeDown was a response to the way Michael Brown was initially pictured in the media. Instead of using photographs in a graduation picture or in a sports team, reporters often used photo of Brown extending his fingers. The choice of the photo was criticized as the gesture that could be interpreted as a gang sign. African - American users started sharing pictures of themselves at their best - with positive connotations - juxtaposed with images that would gather less sympathy, using the hashtag to suggest the negative photo would be used in the news to report on their death. \#IfTheyGunnedMeDown hashtag has been used on Twitter over 168000 times in first three days of the protests [Vega, 2014]. \#HandsUpDontShoot is a gesture and slogan that has echoed across U.S. since protests began. Witnesses said that Brown had his hands raised in surrender, a classic gesture of surrender to authority, mouthing the words "Don't shoot" as his last words before being shot [Ye Hee Lee, 2015]. Protesters in Ferguson, have turned it into a defiant symbol and a rallying cry.

Example of \#BlackLivesMatter denies Morozov's plea that activism on social media can be qualified as "slacktivism". For him slacktivism is a feel-good online activism that has zero political or social influence, it gives participators an illusion of significant impact on the world. He also thinks, that slacktivism is the best type of activism for the lazy generation, without any risks and threats connected with real activism [Morozov E., 2009]. Shirky, in contrary to Morozov, he underlines the supreme power of social media as a means of collective action and that social media have become tools to coordinate almost all political movements in the world [Shirky C., 2011]. Hashtag activism in Ferguson was in line with Shirky's theory, despite leading people to the streets and coordinating protests, it also influenced activists to start a new movement.

\section{Discussion}

Ferguson news managed to catch national attention only because there was Twitter - a platform without algorithmic filtering and with global reach. Due to chronological organization of tweets, topics grow to control discussion. Trending starts locally and by getting an attention of journalists and media the story gets broader publics and global range. [Tufekci Z., 2017, p. 159] Brown's story was covered by national media and exemplified the power of online counterpublics to push citizens to become activists and journalists in moments of crisis and to influence wider public debates over the Ferguson events: 
- Discussion over the shooting of Michael Brown (\#MikeBrown and \#Ferguson). Was he a good kid or a criminal (\#NoAngel and \#iftheygunnedmedown)? Were his hands up (\#handsupdontshoot)? Was it necessary to use weapon by the police?

- Discussion over the protests. Were the protests conducted in peaceful manner?

- Discussion over police actions. Was it necessary for the police to wear riot gear? Were the police actions legitimate (\#PoliceBrutality)?

- Discussion over the decision of the grand jury. Should Police officer Darren Wilson have been indicted (\#Justice4All)? Was justice served? (\#JusticeForMikeBrown)?

- What is the key problem that causes similar situations? Is it racial (\#BlackLivesMatter)?

Ferguson is not an isolated case, there were more unrests, riots and revolutions driven by Twitter and social media called "Twitter revolutions" - that term was initially used by Morozov in relations to protests in Moldova in 2009. [Morozov, 2009]. Governments in several countries have noticed the revolutionary power of Twitter and have banned it either in full: in China, North Korea and Iran; or partially, by censoring its content like for example in Turkey, Venezuela or Russia. There is a growing number of voices questioning Twitter as a last stronghold of free speech, asking the company to stop censorship [Meyer M., 2018] [Tena A.L., 2017], but there is always a contrary opinion saying that the lack of censorship allows terrorists and criminals to plan their events.

\section{Conclusion}

The objective of the article was to analyze the role of Twitter in the first week of Ferguson Unrests. The findings of work have verified three hypotheses. Firstly, that activists used Twitter as an instrument to communicate the events and to organize the protests. The intensity of Ferguson related tweets went up rapidly during the first week of unrests breaking the level of 3000 tweets per minute on the 13th of August [Tufekci, 2014]. Secondly, that Twitter has become a powerful tool of civil journalism. Twitter's influence on the national debate surrounding the events in Ferguson is indisputable [Fung, 2014]. The wide access to the social media allows citizens to feel closer connections to their communities, as well as gives the opportunity for more leveled and fair reporting. Last but not least, that "hashtag activism" can trigger thr creation of a new social movement. This is the case of Black Lives Matter, an international movement of activists that fights with violence and racism towards black people, it regularly holds protests not only in the USA, but its range spawned around the globe. They are actively taking part in protests and demonstrations in Australia, Canada and United Kingdom. These results suggest that the use of Twitter and social media in general will be a key factor in the success of the future national liberation movements, protests, demonstrations and revolts.

\section{References}

BARTHEL M., SHEARER E., GOTTFRIED J., MITCHEL A., (2015), The Evolving Role of News on Twitter and Facebook, [online: February 3, 2018], www.journalism.org/2015/07/14/the-evolving-role-of-news-on-twitterand-facebook/

BONILLA Y., ROSA J. (2015), \#Ferguson: Digital protest, hashtag ethnography, and the racial politics of social media in the United States", American Ethnologist, vol. 42, issue 1, p. 4 - 17

BR00KS R., 2015, Hashtags Explained: The Complete Guide to Hashtags in Social Media, [online: February 3, 2018], http://www.takeflyte.com/hashtags-explained,

CARPENTIER M. (2015), 'Things will never be the same': the oral history of a new civil rights movement, [online: November 27, 2017], https://www.theguardian.com/commentisfree/2015/aug/09/oral-history-civil-rights-movement-ferguson

CARR D, (2014), View of \#Ferguson Thrust Michael Brown Shooting to National Attention, [online: November 28, 2017], https://www.nytimes.com/2014/08/18/business/media/view-of-ferguson-thrust-michael-brown-shoot- 
ing-to-national-attention.html

DALY N., 2014, Twitter Chat: Can hashtag activism have real impact?, [online: March 22, 2018], https://www.pbs.org/newshour/nation/twitter-chat-can-hashtag-activism-real-impact

DUGGAN, M., ELLISON, N. B., LAMPE, C., AM LENHART, A., \& MADDEN, M. (2015), Frequency of social media use. [online: February 3, 2018], http://www.pewinternet.org/2015/01/09/frequency-of-social-media-use-2/ FORTUNE.COM, (2015), World's Greatest Leaders, [online: February 2, 2018], www.fortune.com/worlds-greatest-leaders/2015/johnetta-elzie-and-deray-mckesson-11/

FREELON D., MCILWAIN C., CLARK M., 2016, Beyond the hashtags: \#Ferguson, \#Blacklivesmatter, and the online struggle for offline justice, [online: January 3, 2018], http://archive.cmsimpact.org/blmreport

FUNG B., 2014, Watch Twitter explode along with Ferguson, [online; 26 April, 2018], https://www.washingtonpost. com/news/the-switch/wp/2014/08/14/watch-twitter-explode-along-with-ferguson/?utm_term=.3c0365f02642

GRINBERG E. (2014), What \#Ferguson stands for besides Michael Brown and Darren Wilson, [online: November 28, 2017] http://edition.cnn.com/2014/11/19/us/ferguson-social-media-injustice/index.html

JACKSON S., WELLES B., (2015) \#Ferguson is everywhere: initiators in emerging counterpublic networks, Information, Communication \& Society, vol. 192016 issue 3, [online: March 28, 2018], www.tandfonline.com/ doi/full/10.1080/1369118X.2015.1106571

KANG J.C., 2015, Our demand is simple: stop killing us, [online: March 28, 2018], https://www.nytimes. com/2015/05/10/magazine/our-demand-is-simple-stop-killing-us.html

LEONOWICZ-BUKAŁA I., MARTENS A., OCHNIO J., (2015), Twitter - narzędzie komunikacji w rękach dziennikarzy, Conference: Interdyscyplinarna konferencja: Język a media. Zjawiska językowe i komunikacyjne we współczesnych mediach, Uniwersytet Pedagogiczny, Kraków, 5 - 6 marca 2015; 03/2015

LEWONTIN M., (2016), \#Ferguson: How Twitter helped empower ordinary residents, [online: November 27, 2017], https://www.csmonitor.com/Technology/2016/0124/Ferguson-How-Twitter-helped-empower-ordinary-residents

LUIBRAND S., 2015, How a death in Ferguson sparked a movement in America, [online: March 24, 2018], https:// www.cbsnews.com/news/how-the-black-lives-matter-movement-changed-america-one-year-later/

ŁOKIĆ P., 2014, Aktywność polskich dziennikarzy w serwisie Twitter - analiza wybranych przypadków, „e-Politikon. Kwartalnik Naukowy Ośrodka Analiz Politologicznych" 2014, nr XII: Dziennikarstwo w dyskursie politycznym, s. 146, [online: 24.03.2016], http://oapuw.pl/wp-content/uploads/2015/06/e-Politikon-12-2014.pdf

MANDARO L., SNIDER J., (2014), 300 Ferguson Tweets: A day's work for Antonio French, [online January 3, 2018], https://www.usatoday.com/story/news/nation-now/2014/08/25/antonio-french-twitter-ferguson/14457633/

MASON P., (2012), Global unrest: How the revolution went viral, [online: December 12, 2017], https://www. theguardian.com/world/2012/jan/03/how-the-revolution-went-viral

MCDONALD B., ARCHDEACON C., CHAVAR A.J., (2015), They Helped Make Twitter Matter in Ferguson Protests, [online: November 28, 2017], https://www.nytimes.com/2015/08/11/us/twitter-black-lives-matter-ferguson-protests.html

MILLER Z.J., (2014), Obama: 'No Excuse' for Ferguson Violence, [online: February 2, 2018], www.time. com/3606492/obama-ferguson-violence-grand-jury-announcement/

MISTEWICZ E., Twitter. Sukces komunikacji w 140 znakach. Tajemnice narracji dla firm, instytucji i liderów opinii, Gliwice 2015,

MOFFITT K., (2014), How to follow what's unfolding in Ferguson on Twitter, [online: December 12, 2017], https:// www.bizjournals.com/stlouis/blog/2014/08/how-to-follow-what-s-unfolding-in-ferguson-on.html

MOROZOV E., 2009, Brave new world of slacktivism, [online: March 28, 2018], https://www.npr.org/templates/ story/story.php?storyld=104302141

MOROZOVE., 2009, Moldova's Twitter Revolution, [online:March28, 2018], http://foreignpolicy.com/2009/04/07/ moldovas-twitter-revolution/

MURTHY, D. 2011. Twitter: Microphone for the masses?, Media Culture and Society, 33(5), 779 - 789., [online: December 12, 2017], https://www.dhirajmurthy.com/wp-content/uploads/2012/04/Twitter-Microphone-for-the-masses.pdf

R. L. G., 2015, Johnson: Words of the year \#BlackLivesMatter, [online: March 24, 2018], https://www.economist. com/blogs/prospero/2015/01/johnson-words-year-0

SANCHEZ R., LAWLER D., (2015), Ferguson: timeline of events since Michael Brown's death, [online: November 
28, 2017], www.telegraph.co.uk/news/worldnews/northamerica/usa/11242108/Ferguson-timeline-of-eventssince-Michael-Browns-death.html

SAWICKA Z., (2017), Wpływ nowych mediów na przemiany polityczne wybranych państw Bliskiego Wschodu na przykładzie Arabskiej Wiosny, Warszawa - Rzeszów 2017, Wyższa Szkoła Informatyki i Zarządzania z siedzibą w Rzeszowie

SHEARER E., GOTTFRIED, (2017), News Use Across Social Media Platforms 2017, [online: February 3, 2018], http:// www.journalism.org/2017/09/07/news-use-across-social-media-platforms-2017/

SHIRKY C., 2011, The policical power of social media, [online: March 28, 2018], https://www.foreignaffairs. com/articles/2010-12-20/political-power-social-media

SICHYNSKY T., 2016, These 10 Twitter hashtags changed the way we talk about social issues, [online: January 5, 2018], https://www.washingtonpost.com/news/the-switch/wp/2016/03/21/these-are-the-10-most-influential-hashtags-in-honor-of-twitters-birthday/?utm_term=.3100c9513887

STATISTA, (2017), Number of monthly active Twitter users worldwide from 1st quarter 2010 to 3rd quarter 2017 (in millions) [online: February 3, 2018], https://www.statista.com/statistics/282087/number-of-monthly-active-twitter-users/

SZEWCZYK M., 2017, Pop-ewolucja czwartej władzy, Nauki o mediach i komunikacji społecznej: Krystalizacja dyscypliny w Polsce. Tradycje, nurty, problemy, rezultaty., ASPRA, Warszawa 2017

TUCKER J., (2014), Tweeting Ferguson: how social media can (and cannot) facilitate protest, [online: November 24, 2017], http://www.washingtonpost.com/blogs/monkey-cage/wp/2014/11/25/tweeting-ferguson-howsocial-media-can-and-can-not-facilitate-protest/

TUCKER J., METZGER M., PENFOLD-BROWN D., BONNEAU R., JOST J., NAGLER J., 2015, Protest in the Age of Social Media, [online: March 28, 2018], https://medium.com/carnegie-corporation-international-peace-and/ protest-in-the-age-of-social-media-7ae9fd940b06

TUFEKCI Z., (2017), Twitter and Tear Gas. The power and fragility of networked protest, New Haven \& London 2017, Yale University Press, [online: March 22, 2018], https://www.twitterandteargas.org/downloads/twitterand-tear-gas-by-zeynep-tufekci.pdf

TUFEKCI Z., (2014), What Happens to \# Ferguson Affects Ferguson: Net Neutrality, Algorithmic Filtering and Ferguson, [online: April 26, 2018], https://medium.com/message/ferguson-is-also-a-net-neutrality-issue-6d2f3db51eb0

VEGA T., 2014, Shooting Spurs Hashtag Effort on Stereotypes, [online: March 22, 2018], https://www.nytimes. com/2014/08/13/us/if-they-gunned-me-down-protest-on-twitter.html

YE HE LEE, 2015, "Hands up, don't shoot" did not happen in Ferguson, [online: March 22, 2018], https://www. washingtonpost.com/news/fact-checker/wp/2015/03/19/hands-up-dont-shoot-did-not-happen-in-ferguson/?utm_term=.c1bdd4317169 